\title{
Getting to Know Learning Disability and its Management
}

\author{
Suhana Syed Burhan 1 , Prof. Sara Begum 2
}

\section{ABSTRACT:}

The study aims to give an essay type theoretical background about the perspectives and knowledge of the Learning disability. The study initialized by addressing the conception and discovery of Learning disability. It brings to our knowledge that the Learning disability is still misinterpreted, unapproved, misdiagnosed and mishandled. A sadder part is parents and teachers still struggle to notice the presence of disorders of learning disability in the child therefore they need a simplistic and convenient benchmark to know its existence. They need to have certain instructions to deal with academic difficulties and behavioural issues which arise out of the different disorders of Learning Disability: Dyslexia, Dysgraphia, Dyscalculia and Dyspraxia. In this context to understand and not to misjudge or label the child, there is a need to educate oneself through various organizations and meet ups with professionals of the field. Thus the current study has suggested some useful guidelines to identify the characteristics, common errors, direction for management and remediation of the Learning disability. On the whole people seem to be oblivious to such an Invisible disability. Also the study has analyzed the importance of teamwork around the Child with Learning disability which transforms into an optimistic circle thereby passing guidance and solutions to each other.

Keywords: Learning disability; Dyslexia; Dyscalculia; Dysgraphia, Dyspraxia

\section{INTRODUCTION:}

Achild with learning disability struggles with brain's inability to receive process, store, respond and communicate information. Learning disability consists of number of disorders which usually co-morbid with problem in reading, writing, comprehension, mathematics and some of the behavioural-social-cognitive functions. It is also known by various other names Specific Learning Disabilities, Specific Developmental Disabilities, Developmental Disorder of Scholastic Skills, Academic Skills Disorder, Minimal Brain Dysfunction, and also recognized by its types Dyslexia, Dyscalculia, Dysgraphia and Dyspraxia. It is a childhood disorder which long last till you age. At every developmental stage a child will face numerous academic and nonacademic expectations and for the child having any form of learning disability it would be a difficult task to tackle them independently.

1PhD research Scholar, Jamia Millia Islamia, New Delhi

2Professor, Department of Education, Faculty of IASE, Jamia Millia Islamia, New Delhi

(C) 2015, S Burhan, S Begum; licensee IJIP. This is an Open Access Research distributed under the terms of the Creative Commons Attribution License (http://creativecommons.org/licenses/by/2.0), which permits unrestricted use, distribution, and reproduction in any Medium, provided the original work is properly cited. 
When such children are incapable of achieving the especially the academic goals they are frequently labelled as Lazy, Mischievous, Dumb, or Delinquent child. Parents and other family members would race through different kinds of emotional outburst when they finally realise something doesn't seems right in their child.

In this context, Larry B. Silver, M.D. (2010) said Learning disabilities are definitely School disabilities. However, it is equally critical for parents and for other adults who work with these children and adolescents to understand that Learning disabilities are also life disabilities. The same disabilities that interfere with reading, writing, and arithmetic also interfere with sports, and other activities with family life, and with getting along with friends.

Usually Teachers and Parents choose to ignore some of the major root causes of the significant underachieving performance of the child. It's very unfortunate when some of the real causes such as speech and hearing problem, low vision, neurological dysfunction, delayed developmental milestone, ADHD or poor eye-hand coordination are neglected. These 'HIDDEN' characteristics of Learning Disability are playing crucial role in interfering with the academic performances, behaviors and social skills among the children. One must keep in mind that a child having learning disability usually has intact average or above average intelligence. Teachers or professionals must be very careful while diagnosing these children, as many a time it is confused with slow learners or delayed academic achievers.

\section{Discovery and recognition of Learning Disability:}

Samuel kirk (1963) had discovered the term Learning Disability and it is still used to describe children who have disorders in development in language, speech, reading and associated communication skills needed for social interaction. He also took precaution in not including children who were having mental retardation or any kind of sensory impairment (Blindness and Deafness).

According to The learning disabilities Association of America (LDA) Learning Disability includes the effect of the disability on self-esteem, education, vocation (job), and activities of daily living (ADLs)

The National Joint Committee on Learning Disabilities of USA (1994) stated Leaning Disabilities is a generic term that refers to a heterogeneous group of disorders manifested by significant difficulties in the acquisition and use of listening, speaking, reading, writing, and mathematical abilities. These disorders are intrinsic to the individual and presumed to be due to central nervous system dysfunction. Even though a learning disability may occur concomitantly with other handicapping conditions (such as sensory impairment, mental retardation, social and emotional disturbance) or environmental influences (such as cultural differences, insufficient inappropriate instruction, psychogenic factors), it is not the result of those condition or influences. 
According to Sara Begum (2008) Learning Disabilities are problems that affect the brain's ability to receive process, analyze or store information. These problems can make it difficult for a student to learn as quickly as someone who isn't affected by learning disabilities.

\section{SPECIFIC TYPES OF LEARNING DISABILITY:}

Learning disability consists of different disorders namely Dyslexia which is a problem in reading, Dysgraphia which is a problem during writing, Dyscalculia which is a problem in mathematics and Dyspraxia which is problem motor functioning. Defining each one reflects the real nature of the underlying problems of a Learning Disability.

Dysgraphia: According to Johnson and Myklebust (1967) there are three types of writing disorders: Dysgraphia, Defective revisualization and formulation and syntax deficits. Dysgraphia was described as a visual motor integration disorder which interferes with the memory and execution of the motor patterns needed to write or copy letters, words and numbers.

Dyscalculia: Johnson and Myklebust (1967) stated arithmetic or mathematics may also be caused by an inability to revisualise numbers, an inability to form written numbers graphically, or an ability to remember instruction.

Dyslexia: In April 1968 the definition of Dyslexia was devised by World Federation of Neurology's Research Group on Developmental Dyslexia and World illiteracy, it stated "A disorder in children who, despite conventional classroom experience fail to attain the language skills in reading, writing and spelling commensurate with their intellectual abilities."

Dyspraxia: Often signifies general motor clumsiness. It is problem with sensory integration causing specific \& significant impairment in motor skills such as Fine motor and Gross motor, and problems in daily life activities. It also affects the controlling of the pitch and articulation of voice.

According to ICD-10 (2010) and DSM-IV (1994) the disorders of Learning Disability is specified under different sections and headings with codes : Reading disorder (ICD-10 and DSM-IV codes: F81.0/315.00), Disorder of Written Expression (ICD-10 and DSM-IV-TR codes 315.2), Speech and language disorders can also be called Dysphasia/Aphasia (coded F80.0F80.2/315.31 in ICD-10 and DSM-IV), Math disability (ICD-10 and DSM-IV codes F81.23/315.1) and Non ICD-10/DSM : Nonverbal learning disability and Disorders of speaking and listening

According IDEA (2004) a specific learning disability (SLD) is defined as A disorder in one or more of the basic psychological processes involved in understanding or in using language, spoken or written, that may manifest itself in the imperfect ability to listen, think, speak, read, write, spell, or do mathematical calculations, including conditions such as perceptual disabilities, brain injury, minimal brain dysfunction, dyslexia, and developmental aphasia. Specific learning disability does not include learning problems that are primarily the result of visual, hearing, or 
motor disabilities, of mental retardation, of emotional disturbance, or of environmental, cultural, or economic disadvantage.

\section{MANAGEMENT OF CHILDREN WITH LEARNING DISABILITY:}

\section{A handy criterion ascertaining Learning disability:}

The breakthrough discovery of Learning Disability led to further search for the genuine characteristics which will denote the presence of learning disability among the children. Parents and Teachers needed a substantial knowledge or guidelines to determine the manifested problems in the different learning areas of the child.

Johnson and Myklebust (1967) gave guidelines for the teachers and parents that can follow to see if the child meets the legal definition of learning disability:

1. A score of 90 or above should be obtained in the performance of verbal areas of an intelligence test

2. Visual acuity deviations should not exceed $20 / 40$ with corrections

3. Reduction in auditory acuity should not exceed a thirty to thirty five decibel loss with best correction

4. Only minor motor deficits should be observed

5. No primary emotional conflict should be observed

Thus these criteria were not sufficient enough to differentiate the learning disability so in 1976 it was proposed for addition of some specific criteria.

Before going into the in-depth diagnosis of the child an educator or parents can identify the presence of learning disability by observing that the childeven after given an adequate assistance and having an average or above average intellect, tendency and age appropriate task given, he/she is not being able to perform any of the basic components of reading, writing and mathematics. Thereby a major gap between his performance and intelligence levels shows a sufficient hint of learning disability.

One must also exclude several conditions which do not distinguish a child having learning disability such as low level of Intelligence (I.Q.), severe sensory and motor impairment (such as Visual Impairment, Hearing Impairment, handicapped, Cerebral Palsy), emotional and social problems as well as children from different backgrounds and situations who could also be a first learner of their family.

\section{The characteristics and common errors of Learning Disability:}

According to A. KenethKavale (2001) the many vagaries associated with identification are the primary reason for the difficulty in deciding about the presence or absence of LD. The lack of rigor in the diagnostic process has led to an accelerated rate of LD identification and has led LD to become the largest category in special education." 
The very first sign of learning disability that gets noticed is when the child starts his education. At home more often parents are confused about the mistakes done by their child during the activities of daily living, they would rather name it as a clumsy nature of the child. The situation becomes worrisome only when it starts hindering the child performances at school then eventually parents and teachers starts noticing and differentiating with what is normal and what is not.

It is a very common situation where a child doesn't have the courage to speak out his problems, so it becomes the duty of the teachers to see and check the errors in their Reading, Writing and mathematics as the initial and most common signs of Learning disability. Due to these problems a child sometimes isolate himself or becomes social deviants. Thus it is a group effort to work upon academics, social, emotional and behavioural issues all together at a same time.

Parents, siblings, teachers, relatives and even the neighbors can easily notice the existence of Learning Disability before going through a formal assessment or diagnosis. They can simply follow the underlying characteristics and common errors which are most commonly found among the children with Learning disability:

\begin{tabular}{|c|c|c|c|}
\hline Characteristics & $\begin{array}{l}\text { Dyslexia } \\
\text { (Reading) }\end{array}$ & $\begin{array}{c}\text { Dysgraphia } \\
\text { (Writing) }\end{array}$ & $\begin{array}{c}\text { Dyscalculia } \\
\text { (Mathematics) }\end{array}$ \\
\hline $\begin{array}{l}\text { Problematic areas of } \\
\text { academics mainly } \\
\text { Dyslexia (Reading), } \\
\text { Dysgraphia (Writing) } \\
\text { Dyscalculia } \\
\text { (Mathematics). } \\
\text { Dyspraxia (problem } \\
\text { in voluntary } \\
\text { movements) }\end{array}$ & $\begin{array}{l}\text { Errors with words, } \\
\text { letters or syllables } \\
\text { committed during } \\
\text { reading process: } \\
\text { Repetition, Omitting, } \\
\text { Inserting, Inversion, } \\
\text { Substitution, } \\
\text { Reversals, } \\
\text { Mispronunciation, } \\
\text { difficult words } \\
\text { unrecognized. }\end{array}$ & $\begin{array}{l}\text { Errors committed } \\
\text { during writing such } \\
\text { as spelling, Hindi } \\
\text { Matraas and } \\
\text { conjunct letters are } \\
\text { mistaken forgetting } \\
\text { punctuations and } \\
\text { reverses shapes and } \\
\text { forms of the letters. }\end{array}$ & $\begin{array}{c}\text { Errors during simple } \\
\text { Mathematical } \\
\text { operations Addition, } \\
\text { Multiplication, } \\
\text { Subtraction and } \\
\text { Division. } \\
\text { Unable to count } \\
\text { without the help of } \\
\text { fingers (Finger } \\
\text { counting), Rote } \\
\text { counting }\end{array}$ \\
\hline $\begin{array}{l}\text { Problem in language } \\
\text { areas such a } \\
\text { developmental delay of } \\
\text { language leading to } \\
\text { deficiencies of } \\
\text { vocabulary, and other } \\
\text { language disorders such } \\
\text { as Receptive (Listening } \\
\text { and Reading) and } \\
\text { Expressive language } \\
\text { (Oral and Written } \\
\text { expression). }\end{array}$ & $\begin{array}{l}\text { Difficult Reading } \\
\text { style of child such as } \\
\text { word by word } \\
\text { reading, letter by } \\
\text { letter reading, } \\
\text { strained and high } \\
\text { pitched voice, } \\
\text { inappropriate pauses, } \\
\text { confusion with } \\
\text { punctuation, keeping } \\
\text { a track by finger } \\
\text { pointing. }\end{array}$ & $\begin{array}{l}\text { Unable to plan, } \\
\text { organize and write } \\
\text { his own views, } \\
\text { difficulty in } \\
\text { explaining the } \\
\text { sequence or describe } \\
\text { things through } \\
\text { writing. }\end{array}$ & $\begin{array}{l}\text { Confusion during } \\
\text { place value, decimal, } \\
\text { fraction, word } \\
\text { problems, } \\
\text { multiplication table, } \\
\text { greater than-smaller } \\
\text { than, ascending- } \\
\text { descending, odd-even, } \\
\text { Ordinal positions } \\
\text { (First, Second, Third). }\end{array}$ \\
\hline
\end{tabular}




\begin{tabular}{|c|c|c|c|}
\hline $\begin{array}{l}\text { Impaired structures of } \\
\text { language such as } \\
\text { Phonology, Syntactic, } \\
\text { Semantic, Morphology } \\
\text { and Graphic. }\end{array}$ & $\begin{array}{l}\text { Loses place while } \\
\text { reading, reads very } \\
\text { slowly and } \\
\text { confusion in part- } \\
\text { whole relation of the } \\
\text { words. }\end{array}$ & $\begin{array}{l}\text { vocabulary and does } \\
\text { grammatical, } \\
\text { punctuation errors. }\end{array}$ & \\
\hline $\begin{array}{l}\text { Problematic behaviours } \\
\text { such as Introvert, } \\
\text { Isolation, hyperactivity, } \\
\text { incomplete } \\
\text { task,impatient, } \\
\text { inattentive, unorganized, } \\
\text { disoriented, low level of } \\
\text { self-concept and self- } \\
\text { esteem, bullying, truancy } \\
\text { or delinquency, poor } \\
\text { social relations and } \\
\text { adjustment. }\end{array}$ & $\begin{array}{l}\text { During and after the } \\
\text { Comprehension } \\
\text { reading the child has } \\
\text { problem in } \\
\text { identifying the main } \\
\text { theme, basic facts } \\
\text { and the sequence of } \\
\text { the story. }\end{array}$ & $\begin{array}{l}\text { Unclear and dirty } \\
\text { handwriting, very } \\
\text { small or very big } \\
\text { text size, } \\
\text { overlapping the } \\
\text { letters, inadequate } \\
\text { spacing or bigger } \\
\text { space between } \\
\text { words, skips the } \\
\text { lines, downfall or } \\
\text { upward of the end of } \\
\text { the sentences. }\end{array}$ & $\begin{array}{c}\text { Unable to relate } \\
\text { mathematical symbols } \\
\text { with its symbols such } \\
\text { as Plus }(+), \text { Minus }(-), \\
\text { Multiply }(\times) \text { and } \\
\text { Divide }(\div) \text {, greater } \\
\text { than }(\leq) \text { and smaller } \\
\text { than }(\geq) \text { etc. } \\
\text { Difficulty in } \\
\text { understanding shape } \\
\text { and size such as } \\
\text { square, triangle, circle, } \\
\text { tall-short, big-small } \\
\text { etc. }\end{array}$ \\
\hline $\begin{array}{l}\text { Distorted visual and } \\
\text { auditory perceptions: } \\
\text { Figure ground, Form } \\
\text { Constancy, } \\
\text { Discrimination, Closure, } \\
\text { Space, Spatial relations, } \\
\text { Memory, Sequential, } \\
\text { Non-Sequential, } \\
\text { Analysis, and Blending. }\end{array}$ & $\begin{array}{l}\text { Reading errors due } \\
\text { to nervousness, } \\
\text { disorientation caused } \\
\text { by perceptual } \\
\text { problems, inability } \\
\text { to understand the } \\
\text { meaning, } \\
\text { distractions, low } \\
\text { exposure of sight } \\
\text { words and } \\
\text { new/difficult words. }\end{array}$ & $\begin{array}{l}\text { Copying from } \\
\text { blackboard and } \\
\text { writing into } \\
\text { notebook confuses, } \\
\text { awkward grasping of } \\
\text { pen or pencil, sitting } \\
\text { style is not proper } \\
\text { during writing; oral } \\
\text { recitation or note } \\
\text { taking confuses or } \\
\text { delays the writing. }\end{array}$ & $\begin{array}{l}\text { Confusion during } \\
\text { directions left-right, } \\
\text { up-down, up-down } \\
\text { problems when } \\
\text { written in a single line } \\
\text { or in a form of word } \\
\text { problems. } \\
\text { Digit reversals or } \\
\text { confusion such as } 49 \text {, } \\
96,25,1221 . \\
\text { Cannot identify time } \\
\text { and the minute, } \\
\text { second and hour hand. } \\
\text { Does not recognize } \\
\text { roman numbers. }\end{array}$ \\
\hline
\end{tabular}




\section{Differential diagnosis and Assessment strategies:}

Misdiagnosis is very hazardous for the child's future and his academic performances; it affects both parents and the child immensely. It is important that there is an early identification and early intervention for the Child. To declare the child having Dyslexia, Dyscalculia or dysgraphia one must try to have detailed and organized assessments strategies.

As Joseph J. Lazzaro (2001) stated when adults suspect that a child may have a Learning disability, the best course of action is to have the child evaluated by a professional. The evaluation process will involve standardized testing to compare the child's abilities against children of smaller age and intelligence.

There can be both formal and In-formal testing done by the professional but the important part is to rule in or rule out the conditions leading to the presence of learning disability.

\section{Pointers to keep in mind:}

1. Developmental aspects: Experts working upon the diagnosis must get case history of the developmental aspects and academics then mental age, Achievement age, and his social and behavioural activities age appropriate.

2. Original information: Sources of information must be very correct and authentic as this can serve a very important basis for diagnoses accordingly.

3. Elimination: Other factors which can also influence the academic achievement should also be ruled out such as proper testing of hearing, vision, speech, motor sensory and neurological functions.

4. Records: A proper medical check-up, clinical observation, detailed history of any disorders in the family and record of delayed milestone should be shown to the psychologist and special educators so that they can provide remediation.

5. Grade level assessment: It is mandatory to address the child's grade level performance so to give him remediation accordingly. For instance he may be in Grade $5^{\text {th }}$ but his performance is of Grade $4^{\text {th }}$, thus this means a child had an ability of performing one grade lower but was struggling in higher grade level.

6. Subject wise assessment: Grade level assessment should always be done for all the subjects because it is not always that the child performs same in every subject. He may be affected either in one or more than one subjects and perform as of a lower grade level.

7. Intelligence test: Poor or below average general intelligence is never the co sequencing factor of learning disability one must rely on it only for comparing the discrepancy between his performance and the intelligence level.

8. Formal testing: Standardized tests are used for the Formal assessments which are done by trained professionals and the test results must be shown to the school authorities or organizations/centres (if enrolled). This result would be beneficial for the child as his school will try to accommodate itself accordingly to the child's needs. 
9. Informal Testing: The Informal assessment can be done by general teachers or Special educators; they need to have results from Criterion Tests, Assignments, and Teacher made test papers or curriculum based assessment through Class-test, Weekly test, Half-yearly examination or Yearly examination.

10. Perceptual Testing: Visual and Auditory perception must also be tested. Their performance in the different task will rule out their strengths and weakness over the perceptual grounds.

11. Specific and Curriculum based assessment: The Child must also be evaluated on the reading, writing and mathematical problems. This will give specific result denoting if the child having dyslexia, dysgraphia or dyscalculia.

12. Other test: There can also be testing done for Behavioural, Social-Emotional, Personality and Relationship.

13. Learning styles: Try tapping the Learning style of the child. A child can be a visual learner, auditory learner, kinesthetic learner or a tactual learner.

\section{Providing Remediation and using Teaching Learning Materials:}

To tackle with different forms of problems of Learning disability there is an urgent need of implementing Modification, Accommodation, and Preparation of resources to meet Child's Individual needs. Therefore a basic and most important step is to prepare INDIVDUALISED EDUCATION PROGRAMME (IEP).

As Joseph J. Lazzaro (2001) pointed about IEP; he said that The INDIVDUALISED EDUCATION PROGRAMME is written agreement that describes the nature of the disability and the recommended technologies and services. The agreement is drawn up between the parents of the individual and the educational team at the school.

IEP is prepared for every child with any form disability; it gives appropriate education and training layouts. Its preparation needs information from a reliable sources and input from trained specialist. It always has to cover the developmental aspects of the child so thereby need to include General Physician/paediatrician, Physiotherapy, Occupational therapist, Special educator, Speech therapist, Audiologist, Psychologist.

Corrine E. Kass, Cleborne D. Maddux (2005) mentioned that "The IEP must be based on a comprehensive assessment by a multidisciplinary team. The team must include at least one teacher or other specialist with knowledge in the area of suspected disability. This member of the team, at least should access academic achievement." 
The structure and components of IEP is:

\begin{tabular}{|c|c|}
\hline 1. Background Information & $\begin{array}{ll}\text { - } & \text { Family background } \\
\text { - } & \text { Number of siblings } \\
\text { - } & \text { Socio-economic status } \\
\text { - } & \text { Prenatal-perinatal-postnatal history } \\
\text { - } & \text { Developmental Milestone } \\
\text { - } & \text { History of any Disease or Disability } \\
\text { - } & \text { Any member addicted to } \\
& \text { Smoking/Alcohol/Drug }\end{array}$ \\
\hline 2. Assessments & $\begin{array}{l}\text { - Formal assessments (I.Q test, Achievement test, } \\
\text { Behavioural screening, specific reading, writing } \\
\text { and maths test) } \\
\text { - Informal Assessments (Auditory and Visual } \\
\text { Perception test, Oral test, Observation schedule, } \\
\text { Rating Test, Curriculum based Assessment, } \\
\text { Interview and check-list) } \\
\text { - Grade level Assessment } \\
\text { - Current level functioning (Motor Ability: Fine } \\
\text { motor-Gross motor, Affective Behaviour, } \\
\text { Cognitive skills, Social Skills, Language } \\
\text { Development) }\end{array}$ \\
\hline 3. Setting up Goals & $\begin{array}{l}\text { - Short-term Goals } \\
\text { - Long-term Goals } \\
\text { - Reasonable Goals } \\
\text { - Time taken in achieving Goals } \\
\text { - Extra assistance needed to achieve Goals: } \\
\text { Parents, Teachers help, and Instructional help. }\end{array}$ \\
\hline 4. Smaller Targets & $\begin{array}{l}\text { - Division/ Breakdown of the long term goals } \\
\text { which are achievable through specific period of } \\
\text { time(monthly, quarterly, half-yearly basis). } \\
\text { - Whenever each objective is achieved, the child } \\
\text { comes nearer to the long term Goal. } \\
\text { - Teacher will lay out shorter a goal which } \\
\text { needsthe students to improve upon such as on } \\
\text { their Academics, Behaviour, study habits etc. in } \\
\text { a sequential pattern. }\end{array}$ \\
\hline
\end{tabular}




\begin{tabular}{|c|c|}
\hline 5. Teaching (Planning and Procedure) & 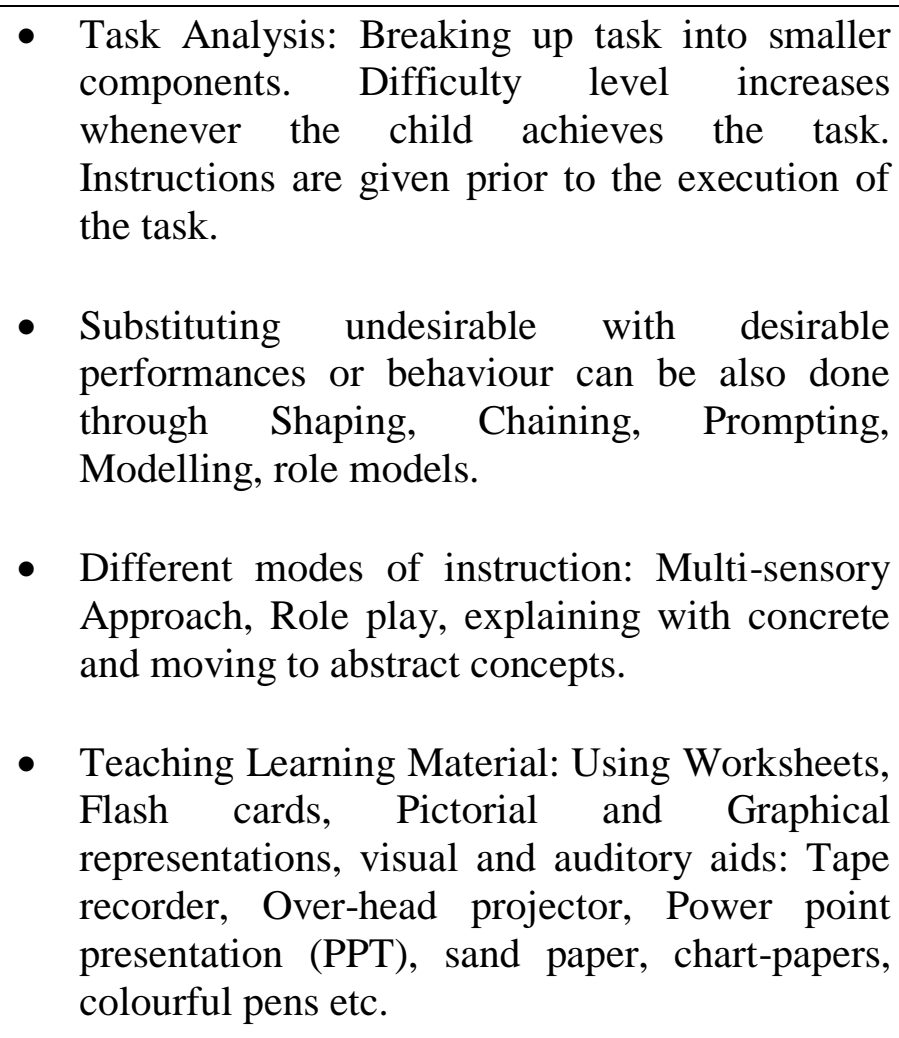 \\
\hline $\begin{array}{l}\text { 6. Therapies and Counselling: } \\
\text { (If necessary) }\end{array}$ & $\begin{array}{l}\text { - If child has any deficits in his Motor } \\
\text { Ability/Social Skills/Language } \\
\text { Development/Behavioural/Emotional/Health } \\
\text { issues then he is given therapies and } \\
\text { counselling. } \\
\text { - Professional Input required by: } \\
\text { Psychologist } \\
\text { Occupational Therapy } \\
\text { Speech Therapist } \\
\text { Counsellor } \\
\text { Doctors }\end{array}$ \\
\hline 7. Terminal Appraisal/Examination/Test & $\begin{array}{l}\text { - Criterion referenced test: Child's performance } \\
\text { will be compared with the already existing set } \\
\text { of scores. } \\
\text { - The result needs to be verbally explained and in } \\
\text { terms of marks/scores/rank which can be easily } \\
\text { understood and interpreted by the parents or } \\
\text { other concerned person. } \\
\text { - The process of scrutiny is prolonged task and } \\
\text { needs feedback which can help the professionals } \\
\text { to plan out for the future planning. }\end{array}$ \\
\hline
\end{tabular}




\section{Precautionary Measures:}

SharynNeuwirth (1993) stated that "Having a child with a learning disability may also be an emotional burden for the family. Parents often sweep through a range of emotions: denial, guilt, blame, frustration, anger and despair. Brothers and sisters may be annoyed or embarrassed by their sibling, or jealous of all the attention the child with LD gets."

The carers of the Child with Learning Disability must be always prepared and be careful, about what they feel and say around the Child. Such cynical and demoralizing atmosphere may induce disruptive behaviour and failure to improvement. To create a healthy learning opportunity for the child one should Dilemmas and pessimistic attitude and start planning and structuring their lives to adhere to Child's individual needs.

It is very well said by Jane Utley Adelizzi and Diane B. Goss(2001) "An ounce of prevention is worth a Pound of cure" when it comes to helping your child to succeed in school. There are many steps you can take to avoid the predictable crises that seem to occur with astonishing regularity in the lives of children and adolescents with learning disabilities. There steps involve creating a context within which children can function at their best.

\section{What to "Say" and "Do":}

1. Special Education: Get the child under the special education programmes and have Individualized Education Programme prepared for him.

2. Inclusive Education: Let the child be in an Inclusive education set-up, where there is availability of resource rooms and special educators.

3. Accommodations: Preparing for accommodation by working on the strengths and accommodating the weakness.

4. Barrier-Free: Providing user friendly environment both in home and school. Removing barriers such noise, extra illuminations, proper sitting arrangements.

5. Technology: Having sufficient and necessary assistive and adaptive technology such as calculators, highlighters, magnifier, talking books etc.

6. Encouragement: It is very necessary, even if a child did a minor improvement he needs to hear positive remarks for further improvement and continuity of the task.

7. Reinforcement: Rewards should be given at every stage of improvement and not doing mistakes which can be in any form, such as material reinforces, gestures, patting on the back, token, praises and written remarks.

8. Social Skills: Improving social skills by making peer groups, role play, arranging outings and joining hobby classes.

9. Responsibility: Give responsibilities and show them you trust them by giving different task at home or school. This will evoke sense of responsibility in the child.

10. Innovations: Do innovative and creative form of teaching the educational or academic task. Such as using colourful or pictorial representation of the lessons, using flash cards, educational games to improve memory, vocabulary etc. 
11. Behaviour management: Trying behaviour modification techniques like Positive and Negative reinforcement, Changing Antecedents, Extinction or Ignoring, Time out, Overcorrection, Differential Rewards, Activity Scheduling, Contingency Contracting, Shaping Chaining, Modelling, Prompting.

12. Helping: Provide Supervision and Guidance for task completion, prompting, giving cues and eventually withdrawing it to help them work independently and effortlessly.

13. Task management: Help them set up goals for themselves and target time to achieve it. Teaching Time concept, Money concept, hygiene, personal care, and Activities of daily Living (ADL).

14. Self-concept: Awareness of self should be taught by making them discover their strengths and weaknesses. Letting them know their changing developmental needs (puberty, adolescence, adulthood) and exploring their abilities.

15. Self-Esteem: Building his self-esteem and confidence by showing his progress to himself and to his parents. He can monitor his own progress as well as errors. Errors will be rectified immediately and progress will be appreciated.

16. Emotionality: Helping to be emotionally open by letting them write journals, make penfriend or a peer pal with whom he can share his emotional state of mind.

17. Relaxation: Engaging them into activities for relaxation and to boost their creativity like Play therapy, Music Therapy, Art therapy or Yoga.

18. Alternatives: As Child with Learning Disability gets into higher classes, there are options for giving the year-end examinations through Distance-Correspondence Mode.

19. Non-Academic activities: Support will be given to Extra-curricular Activities, Hobbies, Sports and exposing much to Vocational Training.

\section{Teamwork to manage the child with Learning Disability:}

A child with learning disability needs an effort and input from all over his surroundings. At home parents and siblings need to pay extra attention and not compelling for task which they cannot perform. Moreover relatives and neighbors should be aware of the child's problem so that they don't misjudge the child. If possible the child should be given counseling to resolve his social and emotional problems. Infect the child with learning disability can be enrolled in a special education centres so that they get special attention after their school hours. Most importantly teachers must be well acquainted with the child's strengths and try to work parallel with the weakness by bringing them to current grade level. Teamwork of people around him gives the child an encouragement and motivation to learn better. If needed the problem of the child can be well addressed to government agencies which can give them concession during their exams, exemption from certain papers and facilities such as provision of assistive and adaptive devices. A cross communication is necessary between the Professionals, Family members, Community people and Government organization has to be constantly available for the Child with Learning Disability. Each one needs to acquaint themselves with the past and current development of the child and they need to resolve the issues providing suggestion and innovation 
to each other. Exchange views with each other; discuss the latest Government provisions, Rights, Therapies and Organizations and institutions for special needs.

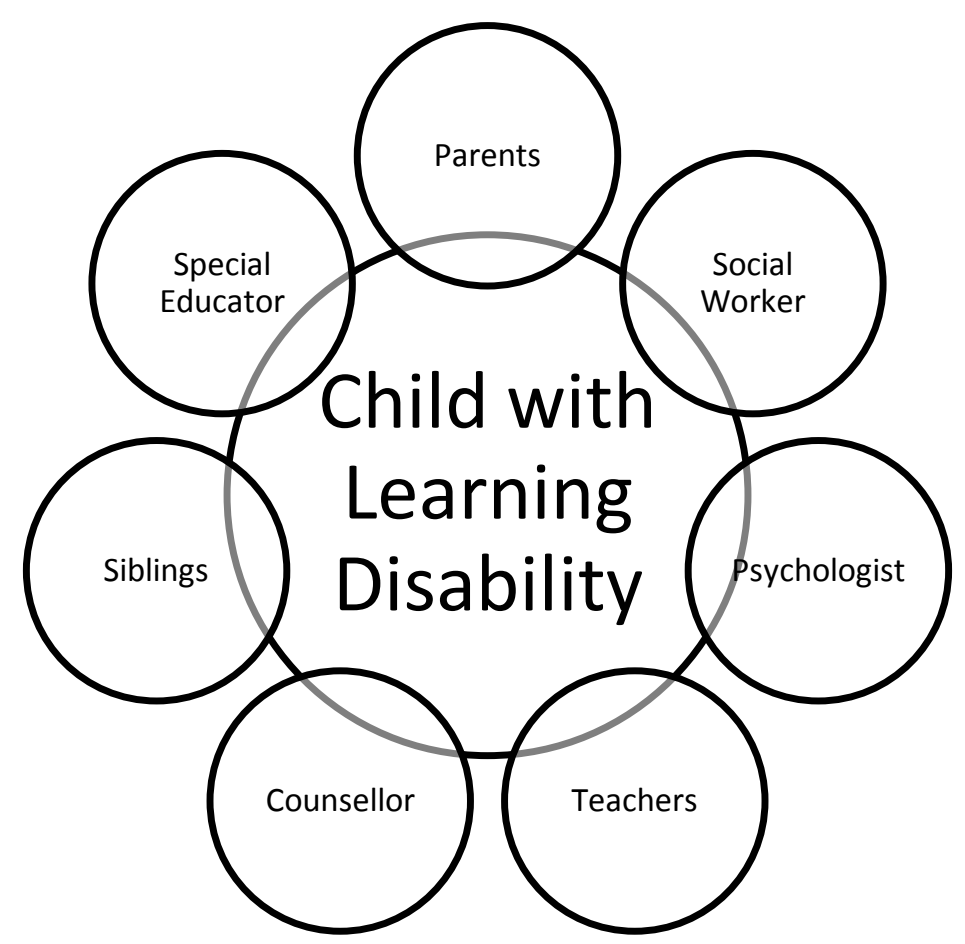

A holistic approach of teamwork by professionals and family members for the development of the Child with Learning disability

\section{CONCLUSION:}

This paper has reviewed the chaotic environment around the Child with Learning disability. It is has been noticed how Parents usually get baffled when they realize that their child has a Learning disability. They often move on to the denial state; they are not ready to accept and believe that they their child is having a learning disability. Initially they put the blame on each other and try to escape from the reality. Thus this reluctant behaviour may lead to arousal of stress and anxiety levels. Eventually when the parents accept the fact then they turn into an overfearing parents and start giving up hope on the child's future. These psychological states of emotions cultivate negative thoughts in the family. Their anxiety level would turn into anger or guilt, and furthermore making them over protective parents.

It is recommended that at this very moment it would be appreciated if at least one of the parents doesn't succumb to the negativity of the situation and try to focus on the strengths of the child. On one hand it is difficult for parents to cope up with the issue and on another the child with learning disability is in a state of commotion. He may not be able to understand his abilities and 
inabilities and wouldn't be able to find the solutions independently. The Child with Learning disability is no less than any other child without learning disability; he needs acknowledgment and appreciation for what he is able to do.

There is also non-requirement of labeling the child with different negative remarks and Teachers must start having positive perspectives towards them. The cases of burnt-out are very common among the teachers especially around the Child with special needs. It may be a challenging task for the teacher to handle and pay special attention towards the Child with Learning disability minority in number among the majority of non-Learning Disabled in the single classroom. Therefore teachers need to be more patient and reduce strictness around them. What teachers need to do is to establish a non-threatening and conducive environment around the Child with Learning disability. She can make the special arrangements and accommodate the Child effectively.

Also before approaching the specialist and professional family member and educators are usually confused and take some careless decisions. Therefore specialist must take initiative to sensitize and prepare convenient as well as informative resources for everyone. To be able to handle such situations the paper has given some very easily understandable facts and management techniques for both layman and the people associated with the child with learning disability. Hence the solution is in one's own hand by taking three simple " $R$ " initiatives Research-Read-Reach.

\section{BIBLIOGRAPHY:}

1. AnupriyaChadha, (2001) A guide to Educating Children with Learning Disabilities, Vikas Publishing House pvt ltd, pp.13-14

2. Corrine E. Kass, Cleborne D. Maddux, (2005), A Human Development View of Learning Disabilities: From Theory to Practice, Charles C Thomas Publisher, pp. 156, http://books.google.co.in/

3. Guidelines for Identifying Children with Learning Disabilities, September 2010, Connecticut State DepartmentofEducation, http://www.sde.ct.gov

4. ICD-10 Version:2010, http://apps.who.int/classifications/icd10/browse/2010/en\#/F81.9

5. Jane Utley Adelizzi, Diane B. Goss, (01 Jan 2001) Parenting Children with Learning DisabilitiesGreenwood Publishing Group, Family \& Relationships, pp. 96, http://books.google.co.in/

6. JosephJ. Lazzaro, (01 Jan 2001), Adaptive Technologies for Learning \& Work Environments, American Library Association, Business \& Economics , pp. 71

7. Kavale, Keneth A, (2001), Discrepancy Models in the Identification of Learning Disability Executive Summary, pp. 3, 2001, http://files.eric.ed.gov/fulltext/ED458758.pdf

8. Learning disability, http://en.wikipedia.org/wiki/Learning_disability 
9. RukminiKrisnaswamy, A Manual for Training of Teachers in Learning Disabilities, Karnataka Parents'Association for Mentally Retarded Citizens (KPAMRC), pp. 25, 70, 73

10. Pasquale J. Accardo and Barbara Y. Whitman et al. (2011), Dictionary of developmental disabilities terminology $3^{\text {rd }}$ edition, Paulh Brookes Publishing, pp. 269

11. Sara Begum, (2008) Understanding Disability Psycho-Social perspective, Global Books Organisation, pp. 26

12. SharynNeuwirth, (01 Jan 1993) Learning Disabilities, National Institute of Mental Health, Diane Publishing, pp. 25

13. T Larry B. Silver, M.D, (10 Feb 2010) The Misunderstood Child, Fourth Edition: Understanding and Coping with Your Child's Learning Disabilities (Google eBook), Crown Publishing Group, Family \& Relationships, pp. 62, http://books.google.co.in/ 